http://dx.doi.org/10.11646/zootaxa.3745.3.4

http://zoobank.org/urn:1sid:zoobank.org:pub:9BCE1113-20A6-4C9F-8CE1-EC5163EDDDCA

\title{
Loricaria luciae, a new species of whiptail catfish (Siluriformes: Loricariidae) from the Paraguay and lower Paraná River basins of southeastern South America
}

\author{
MATTHEW R. THOMAS ${ }^{1,6}$, MÓNICA S. RODRIGUEZ ${ }^{2}$, MARCEL R. CAVALLARO ${ }^{3}$, OTÁVIO FROEHLICH ${ }^{4}$ \\ \& RICARDO MACEDO CORREAA E CASTRO ${ }^{5}$ \\ ${ }^{1}$ Fisheries Division, Kentucky Department of Fish and Wildlife Resources, 1100 Tamworth Lane, Frankfort, KY 40601, USA \\ ${ }^{2}$ Universidade Federal de Viçosa, Campus Rio Paranaíba, Rodovia MG-230 Km 7, CEP: 38810-000, Rio Paranaíba (MG), Brazil \\ ${ }^{3}$ Departamento de Educação, Campus VIII - Paulo Afonso, Universidade do Estado da Bahia, Rua do Bom Conselho 179, CEP \\ 48.608-230, Paulo Afonso (BA), Brazil \\ ${ }^{4}$ Universidade Federal de Mato Grosso do Sul, Laboratório de Zoologia / Centro de Ciências Biológicas e da Saúe, CEP: 79070-900, \\ Campo Grande (MS), Brazil \\ ${ }^{5}$ Laboratório de Ictiologia de Ribeirão Preto, Universidade de São Paulo. Avenida Bandeirantes, 3900, Cidade Universitária, CEP: \\ 14040-901, Ribeirao Preto (SP), Brazil \\ ${ }^{6}$ Corresponding author. E-mail: matt.thomas@ky.gov
}

\begin{abstract}
Loricaria luciae, new species, is described from the the rio Paraguay basin of Bolivia, Brazil, and Paraguay, south to its confluence with the rio Paraná in Argentina. It is distinguished from all congeners by the following combination of characteristics: pectoral girdle entirely naked or with small isolated plates near base of pectoral fin, post-ural plate at base of caudal fin large (plate length 17.0-20.3\% HL), and total lateral plates 32-33 (modally 32). The new species occurs in a variety of habitats ranging from small, seasonally intermittent streams with clear water to large, turbid rivers over sand and mud substrates. It is sympatric with at least three other species of Loricaria in the Paraguay and lower Paraná drainages, including L. apeltogaster Boulenger 1895, L. coximensis Rodriguez et al. 2012, and L. simillima Regan 1904.
\end{abstract}

Key words: Loricariidae, Loricariinae, Loricaria, South America, taxonomy, armored catfishes

\section{Introduction}

The South American genus Loricaria Linnaeus 1758 is a group of armored catfishes distributed in the Amazon, Orinoco, Paraguay, Paraná, and smaller coastal rivers draining the Guiana and Brazilian Shields. The species of Loricaria generally occur over sandy or muddy substrates in a variety of water bodies ranging from insular streams to large lowland rivers, floodplain lakes, and coastal areas (Taylor 1983; Le Bail et al. 2000; Thomas \& Rapp PyDaniel 2008).

A discrepancy currently exists in the number of species recognized in the genus. Following a revision by Isbrücker (1981), 11 nominal species were recognized. A reclassification by Isbrücker in Isbrücker et al. (2001) resulted in the transfer of two species, L. prolixa Isbrücker 1979 and L. lentiginosa Isbrücker \& Nijssen 1978, to a new genus, Proloricaria, reducing the species to nine. Proloricaria was treated as a synonym of Loricaria by Ferraris in Reis et al. (2003) and Covain \& Fisch-Muller (2007) due to a lack of clear diagnostic characters; however, it was recognized as valid by Ferraris (2007). Although the genus Loricaria can be diagnosed, its species can be difficult to distinguish and their taxonomic status, complete distributions, and interrelationships are uncertain (Isbrücker 1981).

Recent work indicates that Loricaria is more diverse than previously considered (Isbrücker 1981, 2001) with six additional species described during the past decade (Rodriguez \& Miquelarena 2003; Thomas \& Rapp PyDaniel 2008; Thomas \& Sabaj Pérez 2010; Rodriguez et al. 2012). Upon examination of loricariine catfish 
Loricaria simillima: ECUADOR: AMAZON BASIN: PASTAZA PROVINCE: BMNH 1880.12.8.77, lectotype, $163.1 \mathrm{~mm}$, rio Bobonaza (Marañon drainage) at Canelos, $01^{\circ} 39^{\prime} \mathrm{S}, 77^{\circ} 46^{\prime} \mathrm{W}, 1880$; BMNH 1880.12.8.78, (paralectotype, $158.0 \mathrm{~mm}$ ), same data as BMNH 1880.12.8.77; BMNH 1880.12.8.79, (paralectotype, 151.3 $\mathrm{mm}$ ), same data as BMNH 1880.12.8.77. BRAZIL: PARAGUAY BASIN: MATO GROSSO STATE: MCP 15755 (4, 215.7-239.4 mm) small stream draining into rio Paraguay ca. $99 \mathrm{~km} \mathrm{~S}$ of Barra do Bugres, $15^{\circ} 45^{\prime} \mathrm{S}$, $57^{\circ} 20^{\prime} \mathrm{W}, 11$ August 1991; MCP $15805(1,178.7 \mathrm{~mm})$, small stream draining into rio Paraguay ca. $69 \mathrm{~km}$ WNW of Cáceres, 1549'S, 58 17’ W, 13 August 1991; MNRJ 21518 (1, $201.5 \mathrm{~mm})$, rio Cuibá about $1 \mathrm{~km}$ from Baús. PARAGUAY: PARAGUAY BASIN: AMAMBAY DEPARTMENT: UMMZ 206802 (1, 264.0 $\mathrm{mm}$ ), rio Apa, ca. $0.5 \mathrm{~km}$ upstream of bridge between Brazil and Paraguay in Bella Vista, $22^{\circ} 06^{\prime} 30^{\prime \prime} \mathrm{S}$, 56³0’W, 27 July 1979. PARAGUARÍ DEPARTMENT: UMMZ 207531 (3, 250.0-263.0 mm), small bay along rio Tebicuary at km 159 and just $\mathrm{N}$ of new bridge on Rte 1 at Villa Florida, 26 $24^{\prime}$ 'S, 57 ${ }^{\circ} 4^{\prime} \mathrm{W}, 27$ August 1979. PRESIDENTE HAYES DEPARTMENT: UMMZ 207148 (4, 168.0-235.0 mm), Riacho Je-e at bridge on paved hwy, ca. $67.5 \mathrm{~km} \mathrm{NW}$ of Benjamin Aceval (rio Aguaray-Guazu drainage), 24³4'54'S, 58 $01^{\circ}$ 'W, 15 August 1979; UMMZ 207570 (2, 261.0-263.0 mm), rio Pilcomayo and adjacent overflow pools at bridge (Puerto Falcon) to Argentina, ca. 12 km WSW Chaco-i, $25^{\circ} 15^{\prime} 48^{\prime}$ 'S, $57^{\circ} 42^{\prime}$ W, 29 August 1979.

Loricaria tucumanensis: ARGENTINA: SALÍ-DULCE BASIN: TUCUMÁN PROVINCE: USNM 88669 (holotype, $121.2 \mathrm{~mm}$ ), rio Salí near San Miguel de Tucumán, 26² $47^{\prime} \mathrm{S}, 6^{\circ} 15^{\prime} \mathrm{W}$, February 1928; USNM 217426 (paratype, $113.1 \mathrm{~mm}$ ), same data as USNM 88669.

\section{Acknowledgements}

We thank the following individuals and institutions for loans of specimens and other forms of assistance: M. Sabaj Pérez and J. Lundberg (ANSP); J. Maclaine (BMNH); M.A. Rogers, P. Willink, and K. Swagel (FMNH); F. Bockmann (LIRP); R. Reis and C. Lucena (MCP); K. Hartel (MCZ); R. Robins and L. Page (UF); D. Nelson (UMMZ); A. Miquelarena (MLP, ILPLA); P. Buckup (MNRJ); O. Oyakawa and M. de Pinna (MZUSP); H. Wellendorf (NMW); J. Williams, L. Palmer, and S. Raredon (USNM); and I. Isbrücker (ZMA). Special thanks to M. Sabaj Pérez (ANSP) for live photos used in Figure 3, A.C. Aquino (LIRP) for preparation of Figure 4, and D. Bunnell for assistance with producing the map used in Figure 5. This study was supported through the All Catfish Species Inventory grant (DEB-0315936) to MRT and a postdoctoral fellowship from FAPESP to MSR (Process no. 2007/04701-2) and MRC (Process no. 2006/54407-0). We also thank the Project "Improvement and management of biological specimen collections at the Departamento de Biologia, FFCLRP- USP" (FAPESP Process no. 09/ 54931-0) and the Programa de Pós-Graduacão em Biologia Comparada for support.

\section{References}

Abell, R., Thieme, M.L., Revenga, C., Bryer, M., Kottelat, M., Bogutskaya, N., Coad, B., Mandrak, N., Balderas, S.C., Bussing, W., Stiassny, M.L.J., Skelton, P., Allen, G.R., Unmack, P., Naseka, A., Ng, R., Sindorf, N., Robertson, J., Armijo, E., Higgins, J.V., Heibel, T.J., Wikramanayake, E., Olson, D., Lopez, H.L., Reis, R.E., Lundberg, J.G., Sabaj Pérez, M.H. \& Petry, P. (2008) Freshwater ecoregions of the world: a new map of biogeographic units for freshwater biodiversity conservation, BioScience, 58, 403-414. http://dx.doi.org/10.1641/b580507

Covain, R. \& Fisch-Muller, S. (2007) The genera of the Neotropical armored catfish subfamily Loricariinae (Siluriformes: Loricariidae): a practical key and synopsis, Zootaxa, 1462, 1-40.

Ferraris, C.J. Jr. (2003) Subfamily Loricariinae (Armoured catfishes). In: Reis, R.E., Kullander, S.O. \& Ferraris, C.J. Jr. (Eds.), Check List of the Freshwater Fishes of South and Central America, Edipucrs, Porto Alegre, Brazil, pp. 330-350.

Ferraris, C.J. (2007) Checklist of catfishes, recent and fossil (Osteichthyes: Siluriformes), and catalogue of siluriform primary types. Zootaxa, 1418, 1-628.

Isbrücker, I.J.H. (1981) Revision of Loricaria Linnaeus, 1758 (Pisces, Siluriformes, Loricariidae), Beaufortia, 31, 51-96.

Isbrücker, I.J.H., Seidel, I., Michels, J.P., Schraml, E. \& Werner, A. (2001) Diagnose vierzehn neuer Gatungen der Familie Loricariidae Rafinesque, 1815 (Teleostei, Ostariophysi). In: Stawikowski, R. (Ed.), Harnischwelse 2, Die Aquarien und Terrarien Zeitschrift, Sonderheft, Eugen Ulmer, Stuttgart, Germany, pp. 17-24.

Le Bail, P.-Y., Keith, P. \& Planquette, P. (2000) Atlas des poissons d'eau douce de Guyane. Tome 2 - fascicule II. Siluriformes, Publications scientifiques du M.N.H.N., Service du Patrimoine Naturel, Paris, 307 pp. 
Rodriguez, M.S. \& Miquelarena, A.M. (2003) Una nueva especie de Loricaria (Siluriformes: Loricariidae) para la cuenca del río San Francisco, Jujuy, Argentina. Anales de la Academia Nacional de Ciensas Exactas, Físicas y Naturales, 55, 139149.

Rodriguez, M.S., Cavallaro, M.R. \& Thomas, M.R. (2012) A new diminutive species of Loricaria (Siluriformes: Loricariidae) from the Rio Paraguay system, Mato Grosso do Sul, Brazil, Copeia, 2012, 49-56. http://dx.doi.org/10.1643/ci-10-192

Sabaj Pérez, M.H. (2013) Standard symbolic codes for institutional resource collections in herpetology and ichthyology: an Online Reference. Verson 4.0. American Society of Ichthyologists and Herpetologists, Washington, DC. Electronically accessible at: http://www.asih.org/ (accessed 1 October 2013)

Taylor, J.N. (1983) Field observations on the reproductive ecology of three species of armored catfishes (Loricariidae: Loricariinae) in Paraguay. Copeia, 1983, 257-259. http://dx.doi.org/10.2307/1444726

Thomas, M.R. \& Rapp Py-Daniel, L.H. (2008) Three new species of the armored catfish genus Loricaria (Siluriformes: Loricariidae) from river channels of the Amazon basin. Neotropical Ichthyology, 6, 379-394. http://dx.doi.org/10.1590/s1679-62252008000300011

Thomas, M.R. \& Sabaj Pérez, M.H. (2010) A new species of whiptail catfish, genus Loricaria (Siluriformes: Loricariidae), from the rio Curuá (Xingu Basin), Brazil.Copeia, 2010, 274-283. http://dx.doi.org/10.1643/ci-09-097

Vari, R.P. (1988) The Curimatidae, a lowland Neotropical fish family (Pisces: Characiformes): distribution, endemism, and phylogenetic biogeography. In: Heyer, W.R. \& Vanzolini, P.E. (Eds.), Proceedings of the Workshop on Neotropical Distribution Patterns. Acad. Bras. Ciências Rio de Janeiro, pp. 343-377. 